\title{
Evsel Kojenerasyon Sistemleri
}

\author{
Gamze Karanfil $^{1 *}$, Batuhan Göçen ${ }^{2}$, Ferdi İnanç3${ }^{3}$, Halil Can Karayel ${ }^{4}$, Ümit Ünver ${ }^{5}$ \\ 1* Karamanoğlu Mehmetbey Üniversitesi, Mühendislik Fakültesi, Enerji Sistemleri Mühendisliği Bölümü, Karaman, Türkiye, \\ (ORCID: 0000-0002-7941-9853), gamzekaranfi186@ gmail.com \\ ${ }^{2}$ Yalova Üniversitesi, Mühendislik Fakültesi, Enerji Sistemleri Mühendisliği Bölümü, Yalova, Türkiye \\ (ORCID: 0000-0001-8141-3330), batuhan1601998@ hotmail.com \\ ${ }^{3}$ Yalova Üniversitesi, Mühendislik Fakültesi, Enerji Sistemleri Mühendisliği Bölümü, Yalova, Türkiye \\ (ORCID:0000-0002-3369-0031), ferdi.inanc.96@gmail.com \\ ${ }^{4}$ Yalova Üniversitesi, Mühendislik Fakültesi, Enerji Sistemleri Mühendisliği Bölümü, Yalova, Türkiye \\ (ORCID: 0000-0001-9835-5042), hllcnkryl@ hotmail.com \\ ${ }^{5}$ Yalova Üniversitesi, Mühendislik Fakültesi, Makine Mühendisliği Bölümü, Yalova, Türkiye \\ (ORCID: 0000-0002-6968-6181), umit.unver@yalova.edu.tr
}

(İlk Geliş Tarihi 01 Mart 2021 ve Kabul Tarihi 27 Haziran 2021)

(DOI: $10.31590 /$ ejosat.889188)

ATIF/REFERENCE: Karanfil, G., Göçen, B., İnanç, F., Karayel, H.C. \& Ünver, Ü. (2021). Evsel Kojenerasyon Sistemleri. Avrupa Bilim ve Teknoloji Dergisi, (25), 198-206.

\section{$\ddot{O} \mathbf{z}$}

Enerji, günümüz toplumunun ve ekonomisinin can damarıdır. Ekonomik, sosyal ve fiziksel refahımızın tümü, yeterli ve kesintisiz enerji üretimine bağlıdır. Enerji üretimi için kullanılan kojenerasyon sistemleri, elektrik ve 1sı enerjisinin tek bir yakıt kaynağından kombine bir şekilde üretilmesi olarak tanımlanabilir. Konvansiyonel sistemlerde sadece elektrik üretimi \%30-35 verim ile gerçekleşebilirken, atık ısının ısınma ve sıcak su ihtiyaçlarının karşılanması için kullanılmasıyla kojenerasyon sistemlerinin verimi \%80'in üzerine çıkabilmektedir. Bu avantajlardan dolayı, gelişmiş ülkelerde, mikro kojenerasyon sistemleriyle binalarda enerji üretimi teşvik edilmektedir. Böylece bina sektörünü enerji tüketen değil enerji üreten duruma getirerek, arz güvenliğini de garanti altına alan politikalar benimsenmektedir. Bu çalışmada, evsel kojenerasyon sistemlerinin tanımı, çeşitleri ve farklı tür uygulamalar için seçim kriterlerini içeren detaylı bir literatür araştırması sunulmuştur. Yapılan araştırmalar neticesinde, uygun evsel kojenerasyon sisteminin seçiminde teknik (uygulama kapasitesi, 1sı-güç oranı vb.), ekonomik (yatırım maliyeti, işletme maliyeti, geri ödeme süresi vb.) ve çevresel (karbonsuzlaştırma vb.) parametrelerin bir arada değerlendirilmesi gerektiği sonucuna varılmıştır.

Anahtar Kelimeler: Dağınık güç sistemleri, Kojenerasyon, Mikro kojenerasyon, Yakıt Hücreleri, Sıfır Enerjili Binalar

\section{Domestic Cogeneration Systems}

\begin{abstract}
Energy is of great importance for today's society and economy. Our economic, social and physical well-being all depend on adequate and uninterrupted energy production. Cogeneration systems used for energy production can be defined as the combined production of electricity and heat energy from a single fuel source. While conventional systems can only produce electricity with $30-35 \%$ efficiency, the efficiency of cogeneration systems can exceed $80 \%$ by using waste heat to meet thermal demands. Because of these advantages, in developed countries, energy production in buildings with micro cogeneration systems has incentives. Policies are adopted to ensure the security of supply by making the building sector not consuming energy but being energy producers. In this study, a comprehensive literature review including the definition, types and selection criteria for different types of applications of domestic cogeneration systems is presented. As a result of the researches, it was concluded that technical (application capacity, heat-power ratio etc.), economic (investment cost, operating cost, payback period etc.) and environmental (decarbonisation etc.) parameters should be considered together in the selection of the appropriate domestic cogeneration system.
\end{abstract}

Keywords: Distributed power plants, Cogeneration, Micro-cogeneration, Fuel cells, Zero Energy Buildings

*Sorumlu Yazar: gamzekaranfil86@gmail.com 


\section{Giriş}

Günümüzde enerjiye olan ihtiyaç gün geçtikçe artmaktadır. Kullanılan enerji kaynaklarının zamanla yetersiz kalması ve geleneksel kaynakların çevreye verdiği zararlardan dolayı yenilenebilir enerji kaynaklarının kullanımı, daha yüksek verime sahip enerji dönüşüm sistemlerinin geliştirilmesi ve özellikle elde edilen enerjinin verimli kullanılmasının önemi daha büyük hale gelmiştir (Karanfil vd., 2020). Ülkemizde de, son yıllarda artan nüfus ve sanayi faaliyetleri ile birlikte yükselen enerji talebimiz ve mevcut enerji kaynaklarımızın sınırlı oluşu ülkemizde enerji kaynaklarının daha verimli kullanılmasına ilişkin çalışmaları zorunlu hale getirmiştir (Demir vd., 2020). Enerji kaynaklarının doğru ve verimli kullanılması ülke ekonomisi üzerindeki enerjiden kaynaklanan maliyetlerin düşürülmesinin yanı sıra sera gazlarının neden olduğu iklim değişikliklerinin azaltılmasına ve enerji arz güvenirliliğinin artırılmasına katkıda bulunur. Konut, hastane, alışveriş merkezi ve eğitim veren binalarda tüketilen enerji dünyada olduğu gibi ülkemizde de toplam enerji tüketimindeki payı oldukça yüksektir (Ener Ruşen vd., 2018).

Rüzgâr türbinleri, fotovoltaik (PV) sistemler, mikro türbinler ve yakıt hücreleri gibi küçük ölçekli güç üretim sistemleri; dağınık güç üretimi (DGÜ) kavramından yararlanılarak tüketici taleplerinin karşılanması için önemli rol oynarlar. Dağınık güç üretimi terimi, merkezi veya uzak yerleşimlerden çok, tüketicilerin yakınına kurulmuş olan küçük ölçekli güç üretim anlamına gelir. Enerji iletimi, dağıtımı ve dönüşümü işlemlerinde önemli miktarda enerji kaybı gerçekleşir. Dağınık güç sistemlerinin, uzun mesafelere iletim ve dağıtım sırasında gerçekleşen kayıpları azaltması, tasarım giderlerinin azalması ve bölgesel voltaj (gerilim) düzenlenmesi gereken ve aşırı yük oluşan koşullarda büyük bir ünite yerine, küçük bir ünite eklenmesine olanak vermesi gibi yararları bulunmaktadır (Kaya vd., 2017). Dağınık güç sistemlerinin dünyadaki uygulamalarından biri de mikro kojenerasyon sistemleridir. Kojenerasyon, kısaca ısıl ve elektrik enerjisi ihtiyaçlarının bir arada tek bir sistem üzerinden karşılandı̆̆ sistemi olarak açıklanabilir ve mikro kojenerasyon ise elektrik enerjisine dayalı kurulu gücü $50 \mathrm{~kW}$ ve altı olan sistemler için kullanılan bir terim olmaktadır (Ciampi vd., 2016; Pravadalığlu, 2012). Mikro kojenerasyon sistemlerinde hem 1sıl hem de elektrik enerjisi dönüşümleri yüksek verimlilikte (\%6595) gerçekleştirilebilmektedir (Onovwiona ve Ugursal, 2006). Ayrıca bu verimli enerji dönüşüm sistemleri, artık kurumlara bağlı kalmaksızın ve elektrik kesintileriyle uğraşmaksızın, enerji güvenliğinde son derece başarılı olan ve ekonomik bir uygulama olan kojenerasyonun hane bazında kullanımını mümkün kılmaktadır. Bununla birlikte çevre için de şebekeden kullanılan enerji ile kıyaslandığında çok daha ekonomik, verimli ve temiz bir alternatif olarak karşımıza çıkmaktadır (IEA, 2009). Bu yönüyle yeşil bina sertifika sistemlerinde ve sıfır enerjili bina yaklaşımlarında tercih sebebi olmaktadır (Erbıyık vd., 2021).

\section{Kojenerasyon}

\subsection{Kojenerasyonun Tanımı ve Kapsamı}

Kojenerasyon terimi, elektrik enerjisi üretimi ve oluşan 1sıl enerjinin yararlı amaçlar için aynı sistem tarafindan üretilmesi anlamına gelir. Kojenerasyon sistemleri, aynı anda bir veya iki tür birincil güç üreten ana taşıyıcı olarak adlandırılan ve Şekil e-ISSN: 2148-2683 1'de gösterildiği gibi ana taşıyıcıdan birincil enerjiyi geri kazanmak için yardımcı bileşenlerden oluşan tek veya hibrit bir enerji kaynağından meydana gelmektedir. Ayrıca birkaç uygulamada kojenerasyon sistemleri sicak su tankı veya batarya gibi depolama cihazları ile donatılmıştır. Depolar, sistem tarafindan üretilen fazla enerjileri depolamak için kullanılmaktadır. Bu konfigürasyonu kullanarak, kojenerasyon, tek güç üretim sistemine kıyasla $\% 80$ 'e varan bir verimliliğe ulaşabilmektedir (Ramadhani vd., 2019). Kojenerasyon sistemleri endüstriyel işletmelerde 100kW'tan 100MW'a kadar rahatlıkla uygulanabilmektedir (Goswami ve Kreith, 2016).

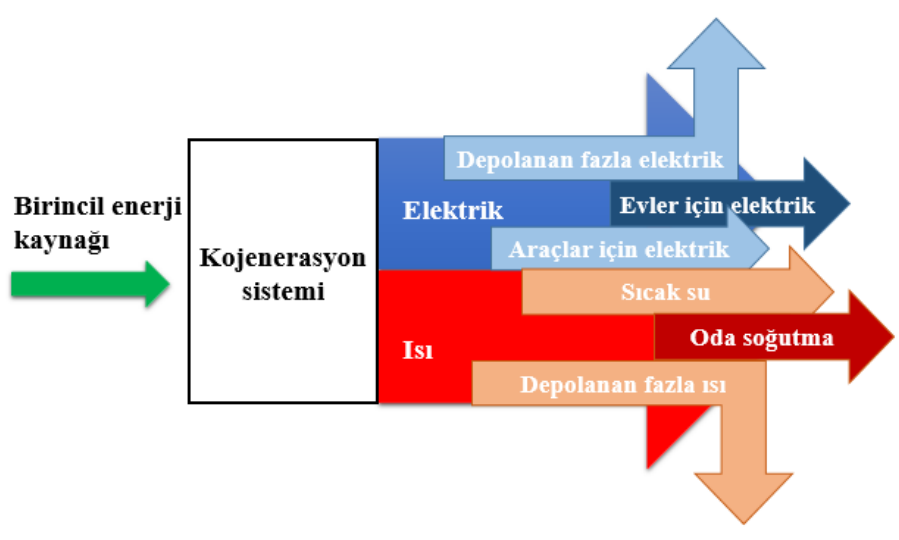

Şekil 1. Kojenerasyon sistem çıktıları

Victoria dönemi (1837-1901) mühendisleri, enerji üretiminden kaynaklanan atık 1sının fabrikada kışın 1sıtma sağlamak için ve bazı durumlarda üretim süreçlerini kolaylaştırmak için kullanılabileceğini fark etmişlerdir. Yirminci yüzyılın başında, mekanik güç yerini aşamalı olarak elektrik gücüne bırakmış fakat atık 1Sı fabrikalarda kullanılmaya devam etmiştir. $\mathrm{Bu}$, bugün bildiğimiz şekliyle kombine 1 s1 ve güç (combined heat and power, CHP) üretiminin ilk formu olmuştur. Fabrikalarda kullanılan CHP sistemlerinden gelen fazla gücün civardaki konutlara ve işletmelerde kullanılmaya başlanması ise evsel kojenerasyon sistemlerinin başlangıcı olmuştur (Belth, 2011). 1973'te başlayan enerji farkındalığının bir sonucu olarak dünyanın dört bir yanındaki endüstriyel tesisler kojenerasyon konseptine artan bir ilgi göstermiştir (Boyce, 2010).

Elektrik enerjisi ihtiyacı genellikle yerel elektrik şebekesinden elektrik satın alarak, 1 sıl enerji ise sahada bulunan kazan veya firın yoluyla karşılanmaktadır. Ancak, bir elektrik santralinde elektrik üretimine 1sı üretimi de eşlik eder. Üretilen bu 1sı enerjisinin santralin egzoz gazları ve soğutma devreleri yoluyla çevreye atılması durumu, büyük bir enerji israfına neden olur. Atık olarak tabir edilen bu 1sı enerjisinin çoğu geri kazanılabilir ve isıl yükleri karşılamak için kullanılabilir durumda olmaktadır. Santralin kojenerasyon sistemine dönüştürülmesiyle enerji dönüşüm verimi \%40-50'lerden \%8090'lara kadar yükseltilebilmektedir (Frangopoulos, 2017). Geleneksel sistemler ile kojenerasyon sistemlerinin karşılaştırmalı gösterimi Şekil 2'de verilmiştir (Goswami ve Kreith, 2016). 


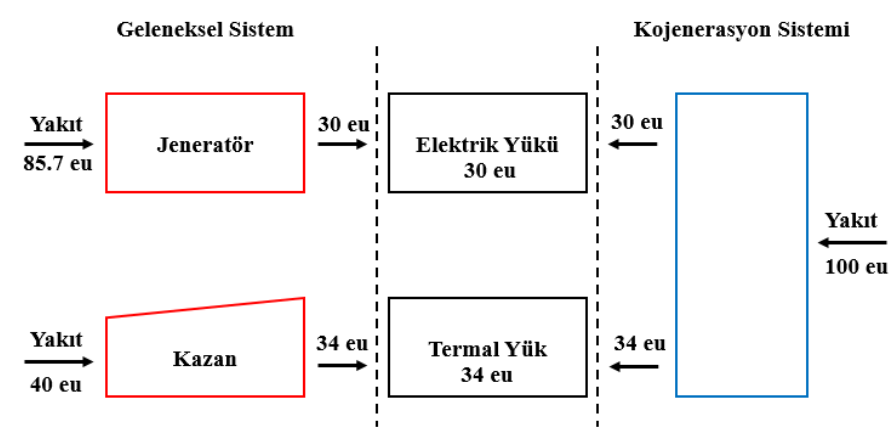

\section{Şekil 2. Geleneksel sistemler ile kojenerasyon sistemlerinin} karşılaştırılması

\subsection{Kojenerasyonun Amacı ve Faydaları}

Geleneksel fosil yakıtlı enerji santralleri \%35-40 verimlilik ile çalışır. $\mathrm{Bu}$ durum yakıtın enerjisinin büyük bir kısmının faydalı enerjiye dönüştürülemediği anlamına gelir. Buna karşılık, kojenerasyon sistemleri \%70 ile \%90 arasında tipik işletme verimliliğine sahiptir. Kojenerasyon santralleri, geleneksel sistemlerde atık olan ısıyı kullanarak aynı emisyon seviyesi için daha fazla çıktı üretir. Ek olarak, kojenerasyon tesisleri genellikle daha küçüktür ve iletim kayıplarını en aza indirmek için enerjiyi kullanacak olan konuma yakın kurulmaktadır. (Flin, 2009).

Birleşik Krallık'ın $\mathrm{CO}_{2}$ emisyonlarının yaklaşık \%35'i elektrik üretiminden kaynaklanmaktadır. ABD'de elektrik üretimi, tüm $\mathrm{CO}_{2}$ emisyonlarının \%24'ünü oluşturmaktadır. Commonwealth Bilimsel ve Endüstriyel Araştırma Örgütü'ne (CSIRO) göre, kömürle çalışan merkezi elektrik üretim tesislerinden üretilen her $1 \mathrm{kWh}$ elektrik, $1 \mathrm{~kg} \mathrm{CO} 2$ emisyonuna neden olmaktadır. Elektrik üretmek için kullanılan farklı yakıt türleri, farklı seviyelerde $\mathrm{CO}_{2}$ emisyonlarına neden olur. Birçok ülke $\mathrm{CO}_{2}$ emisyonlarını önemli ölçüde azaltmak için hedefler belirlemiştir. Minimum emisyonla elektrik üreten yenilenebilir enerji kaynaklarının kullanılması, yüksek $\mathrm{CO}_{2}$ yayan yakıtlardan daha düşük emisyon değerlerine sahip yakıtlara geçilmesi (örneğin kömürün gazla değiştirilmesi), $\mathrm{CO}_{2}$ toplama ve yakalama sistemlerinin geliştirilmesi, üretim verimliliğini arttıran ve dolayısıyla daha az emisyon üreten kojenerasyon sistemlerinin kullanılması, mevcut $\mathrm{CO}_{2}$ emisyonlarını düşürmek için başvurulabilecek yöntemlerden birkaç tanesidir. $\mathrm{Bu}$ yöntemler arasında kojenerasyon, hem enerji dönüşüm verimliliğini arttırmak hem de $\mathrm{CO}_{2}$ emisyonlarını azaltmaya yönelik ihtiyaçları karşılamak için kullanılabilecek mevcut ve kanıtlanmış bir teknolojidir (Flin, 2009).

ABD Çevre Koruma Ajansı'nın (EPA) CHP Ortaklığı, 2007 yılına kadar 335 kojenerasyon tesisinin kurulumunu desteklemesinin 2 milyon arabanın neden olduğu emisyon miktarını yok etmeye veya 2,4 milyon dönümlük bir orman elde etmeye eşdeğer olacak miktarda $\mathrm{CO}_{2}$ emisyonunu azalttı̆̆ belirlenmiştir (US EPA, 2008). ABD'de kojenerasyon kullanımı sonucunda, 2030 yılına kadar binalar için $\mathrm{CO}_{2}$ emisyonunun yaklaşık \%13 (70 megaton) ve endüstri sektörü için \%53 (80 megaton) azalacağı öngörülmektedir. Karbon emisyonu azaltma konusunda sadece kojenerasyon sistemlerini dahi kullanmanın bina yalıtımı, yoğuşmalı kazanlar ve rüzgâr gücünü kullanmaktan daha ekonomik olduğu sonucuna ulaşılmıştır. Kojenerasyon sistemlerinin kullanımı ayrıca $\mathrm{NO}_{\mathrm{x}}$ ve $\mathrm{SO}_{\mathrm{x}}$ gibi bazı atmosferik kirleticilerin emisyonlarının da azaltılmasına katkı sağlamaktadır. Bu katkı özellikle kentsel alanlarda önemli olan hava kalitesinin iyileştirilmesine destek olmaktadır. Örneğin Houston Gelişmiş Araştırma Merkezi tarafından yapılan bir araştırmada Houston-Galveston-Brazoria bölgesine $2600 \mathrm{MW}$ CHP eklemenmesinin, $\mathrm{NO}_{\mathrm{x}}$ emisyonlarını yılda 4700 ile 5440 ton azaltacağını tahmin etmektedir (Tanaka, 2009).

\subsection{Kojenerasyonun Çeşitleri}

\subsubsection{Buhar Türbinli Kojenerasyon Sistemleri}

Buhar türbinli kojenerasyon sistemleri termik santrallerde çok uzun yıllardır kullanılmaktadır. Buhar türbinli kojenerasyon sistemlerinde iş akışkanı su buharıdır. Su buharı, yaklaşık 550$570^{\circ} \mathrm{C}$ sıcaklıklarda buhar kazanından elde edilir (Çengel ve Boles 2013). Buhar kazanında buhar elde etmek için kömür, dizel ya da doğalgaz gibi çeşitli fosil yakıtlar kullanılır. Sistemin basitleştirilmiş şeması Şekil 3'te verildiği gibidir (Moran vd., 2014).

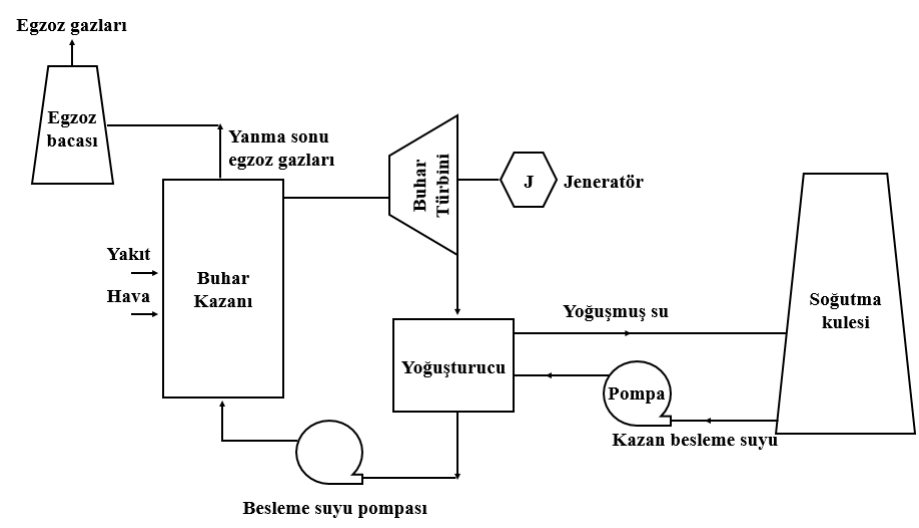

Şekil 3. Buhar çevrimli termik santralinin şematik gösterimi

Şekil 3'te verilen termik santral bileşenlerinden de anlaşılabileceği gibi, elektrik enerjisi üretecek olan jeneratörün mekanik hareketi için yüksek basınçlı kızgın buhar, türbine gönderilir ve türbin hareketlendirilir. Türbin miline bağlı olan elektrik jeneratöründen elektrik enerjisi elde edilir. Türbin çıkışındaki buhar yoğuşturucuya gönderilir. Yoğuşan buhar, sıvı fazda tekrar kazana buhar üretimi için gönderilir ve böylece çevrim tamamlanmış olur (Moran vd., 2014). Yalnız buhar çevrimine göre çalışan termik santrallerde yakıttan bu şekilde faydalanılır. Evsel kojenerasyonun proses yönünden tek farkı, çevrimdeki buharın bir evi veya konutu 1sıtmak için kullanılması ve bu şekilde bir yoğuşma sağlayarak tekrar termodinamik çevrimin sürekliliğinin sağlanmasıdır. Örnek bir mikrokojenerasyon sistemi Şekil 4'te şematik olarak gösterilmiştir (Khartchenko ve Khartchenko, 2014).

Buhar türbinli mikro kojenerasyon uygulamasında gerçekleştirilen ısıtma işlemi için, buhar türbininden çıkan buhar (5-10 MPa, $120-150^{\circ} \mathrm{C}$ ) 1sıtılacak bölgedeki 1sı değiştiricilerine gönderilir (Wang, 2001; Whitman vd., 2013). Is1 değiştiricilerinden elde edilen sıcak su radyatör ya da klima sisteminde mahalli ısıtmak için kullanılır (Ünver ve Kılıç, 2005). Elektrik enerjisi ise kontrol paneli, doğrultucular, dönüştürücüler, transformatörler ve dağıtım sistemleri gibi bileşenler yardımıyla hanelere şebeke elektriği standartlarında ulaştırılır (Fuchs ve Masoum, 2011). Buhar türbinli mikro kojenerasyon sistemleri toplu konut uygulamalarında 
kullanılabilir (McLean-Conner, 2009). Çünkü mikro türbin olarak sınıflandırılan buhar türbinlerinin en küçük boyutları 100$500 \mathrm{~kW}$ arasında güce sahiptir. Bu nedenle toplu konut, bölgesel 1sıtma gibi nispeten büyük ölçekli uygulamalarda buhar türbinli sistemler tercih edilir. Bu sistemler müstakil ya da apartman tarzı binalara uygulanmak için fazla büyüktürler ve tercih edilmezler (Forsthoffer, 2011). Isıl enerji ihtiyacının yüksek ve elektrik enerji ihtiyacının düşük olduğu kojenerasyon uygulamaları için buhar türbinli mikro kojenerasyon sistemleri ekonomik bir yöntem gibi görünebilir. $\mathrm{Bu}$ sistemlerin genel verimlilikleri \%65-\%75 dolaylarındadır (Ünver ve Kılıç, 2007).

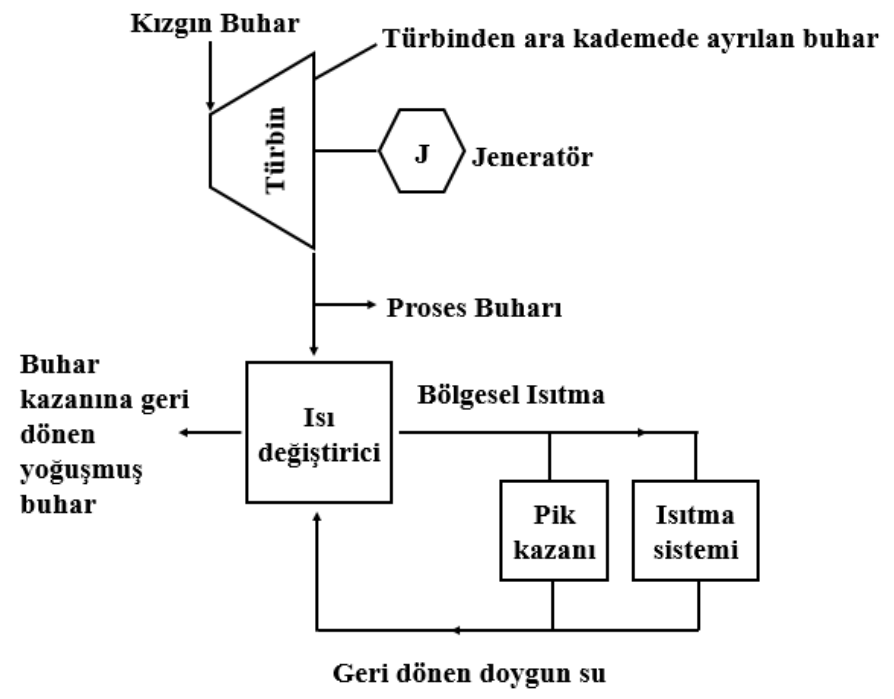

Şekil 4. Buhar türbini kojenerasyon sistemi ile bölgesel ısıtma

\subsubsection{Gaz Türbinli Kojenerasyon Sistemleri}

Gaz türbinleri, Brayton termodinamik çevrimi kullanan içten yanmalı motorlardır. Türbinde elde edilen mekanik enerji, jeneratör bağlantısıyla elektrik enerjisine dönüştürülür (Horlock, 2003). Gaz türbini, buhar türbininden çok daha yüksek sıcaklıklarda, farklı tür bir termodinamik çevrimle, farklı bir mekanizma ile çalışmaktadır (Forsthoffer, 2011). Bu tür sistemlerde, gaz türbini egzozundan çıkan 1sıl enerji ile buhar kazanında kızgın buhar elde edilir. Kazandan gelen buhar, ayrı bir çevrimde buhar türbininde kullanılır. Buhar türbini de başka bir jeneratöre bağlıdır ve oradan da elektrik üretimi gerçekleştirilir (Ünver ve Kılıç, 2017). Eğer uygun şekilde projelendirilirse, buhar türbini çıkışında elde edilen doymuş buhar başka bir kimyasal proseste de kullanılabilir (Kolanowski, 2011; Ünver vd., 2018). Büyük çaplı konut uygulamalarında kullanılan termik santrale benzer gaz türbini kojenerasyon sisteminin şematik gösterimi Şekil 5'te verildiği gibidir (Khartchenko, 2014).

Gaz türbinleri, evsel kojenerasyon uygulaması için daha uygun çözümler sunar. Mikro kojenerasyon uygulamaları için 50 kW'a kadar enerji üreten mikro gaz türbinleri kullanılmaktadır. $\mathrm{Bu}$ durum daha küçük ölçekli uygulama imkânı sunmaktadır (Boyce, 2010). Mikro gaz türbinli kojenerasyon sistemleri büyük ölçekli sistemler gibi karmaşık olmamaktadır (Ünver vd., 2018). Genel olarak bu kojenerasyon sistemlerinde gaz türbininden ayrılan sıcak egzoz gazlarının enerjisi bir 1sı değiştiricisi ile mahalli 1sıtma işlemi için suya aktarılır (Thulukkanam, 2013). Elektrik enerjisi ise gaz türbin miline bağlı jeneratör tarafından üretilir. $\mathrm{Bu}$ sistemler genel olarak paket halinde kurulurlar ve tek e-ISSN: 2148-2683 başına Rankine veya Bryton çevrimlerinden daha verimlidirler. Sistemin elektrik üretim verimi \%35 civarlarındadır ve toplam verimi \%85'lere kadar çıkmaktadır (Abuşoğlu vd., 2013).

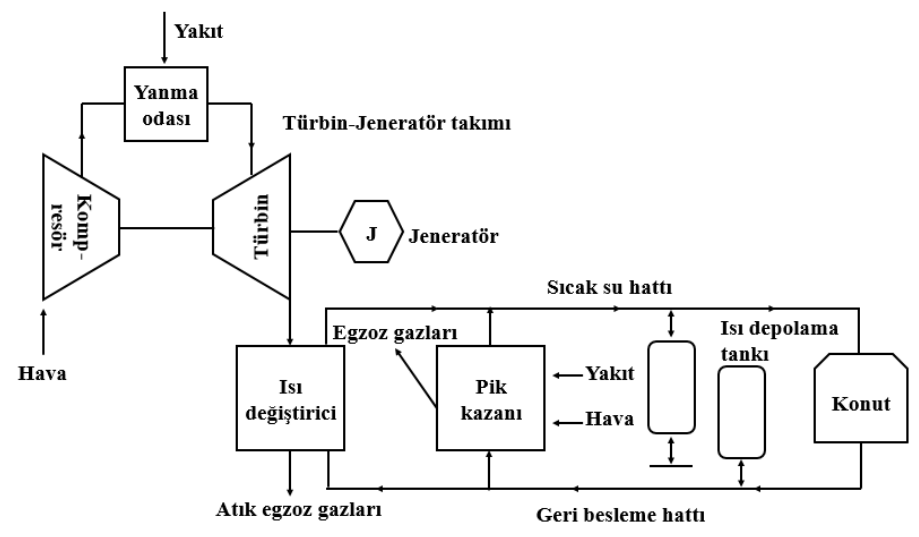

Şekil 5. Gaz türbini kojenerasyon uygulamasının şematik gösterimi

\subsection{3. İçten Yanmalı Motorlu Kojenerasyon Sistemleri}

İçten yanmalı motorlu kojenerasyon sistemleri; benzin, dizel, LPG yakıtları ile çalışan motorları içeren sistemlerdir (Pulkrabek, 1997). Isıl enerjiyi elde etme yöntemi egzoz gazlarının atık 1sılarından ısı değiştiricileri kullanarak sıcak su elde etme şeklindedir. Bu sistemlerde elektrik enerjisi ise motor krank miline bağlı jeneratörle elde edilmektedir (Yavuzdeğer ve Ekinci, 2019). Kojenerasyon motorlarında her pistonun egzozu direk bir 1sı değiştiricisine bağlıdır ve atık 1sıdan anında faydalanılır. $\mathrm{Bu}$ sistemde tek bir 1S1 değiştirici yerine 1S1 değiştirici takımı kullanılmaktadır (Ferguson vd., 2009). Sistemin basit bir şematik gösterimi Şekil 6'da verilmiştir. Bunun yanısıra, 1sıl yükün artması durumunda sisteme yardımc1 bir kazan da eklenebilmektedir (Khartchenko, 2014).

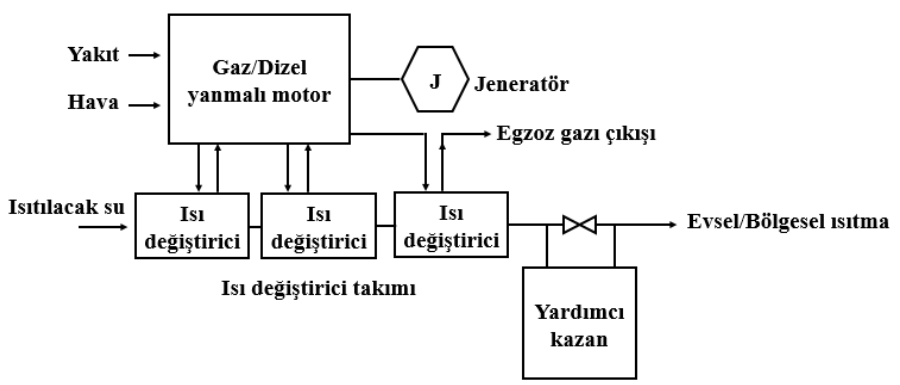

Şekil 6. İçten yanmalı motor ile kojenerasyon uygulaması

Evsel kojenerasyon uygulamalarında mikro kojenerasyon ünitesi paket olarak hazırlanmaktadır. Kontrol sistemi sayesinde, ihtiyaca göre sistem kendini çalıştırıp kapatabilmekte, bu sayede fazla yakıt harcanmasinı engelleyebilmektedir. Bu sistemlerle $5 \mathrm{~kW}$ kadar küçük veya birkaç MW'lık büyük uygulamalar yapmak mümkündür. Basitleştirilmiş proses şeması Şekil 7'de görülmektedir (Khartchenko, 2014).

İçten yanmalı motorlu kojenerasyon sistem verimi \%70$\% 85$ civarındadır. Elektrik ve 1sı üretimi açısından daha dengelidir, eşit yükteki ihtiyaçlar için uygulamaları mevcuttur. 


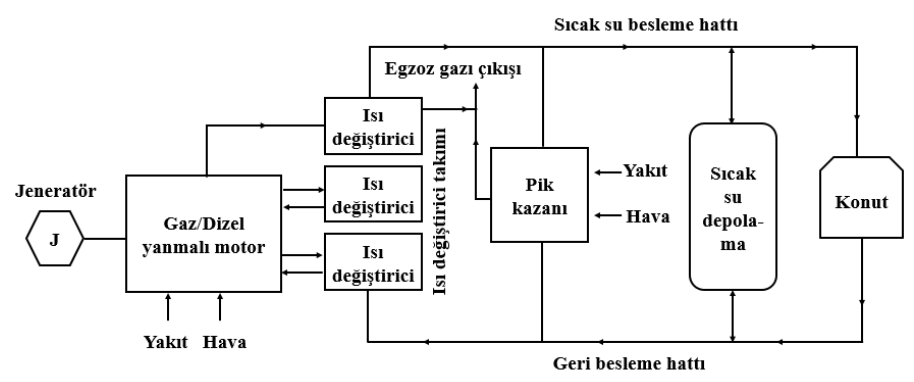

\section{Şekil 7. Geniş kapsamlı içten yanmall motorlu kojenerasyon uygulama prosesinin şematik gösterimi}

\subsubsection{Yakıt Hücreli Kojenerasyon Sistemleri}

Şu anda kullanımda olan üç tane ana mikro-CHP teknolojisi mevcuttur. Bunlar; içten yanmalı motorlar, dıştan yanmalı çevrimler -Stirling motorları, Organik Rankine Çevrimi- ve yakıt hücreleridir. Hâlihazırda kurulu olan ticari mikro-CHP birimlerinin büyük çoğunluğu içten yanmalı motorlara, Stirling motorlarına ve organik Rankine çevrimlerine dayanmaktadır. Elektriksel ve 1sıl üretim arasındaki oran, yanma cihazları için daha düşük oranlarla teknolojiler arasında farklılık gösterir, bu nedenle yüksek isıtma yüklerine sahip büyük binalara daha uygundur. Yakıt hücresi sistemleri ise \% 60'a kadar elektrik verimliliğine ulaşabilir ve bu nedenle otomatik üretilen elektriğin öz tüketim şemaları için uygundur (Gandiglio vd., 2020). Yakıt hücreleri, büyük ölçüde karbondan arındırma potansiyeli vaat eden sürdürülebilir bir kojenerasyon teknolojisi olarak kabul edilmektedir (Sun vd., 2021). Yakıt hücresi temelli kojenerasyon sistemlerine ilişkin araştırma ve geliştirme çalışmaları son 10 yılda artan bir ivme kazanmıştır. Yakıt hücresi tabanlı bir mikro-CHP sisteminin konfigürasyonu, yakıt hücresi tipi, yakıt ve uygulama yeri gibi faktörlere büyük ölçüde bağlı olduğundan değişiklik göstermektedir. Buna karşılık, yakıt hücresi tipi ve yakıt, yakıt işlemcisinin konfigürasyonunu da etkiler. Tüm yakıt hücreleri, anot ve katot adı verilen iki adet elektrot ve bu elektrotları birbirinden ayıran elektrolit tabakasından oluşmaktadır. Elektrotlar iyi birer iyonik ve elektronik iletken olmakla birlikte, elektrolit tabakasından yüksek iyonik iletkenliğin yanı sıra elektronik olarak yalıtkan olması beklenmektedir. Böylelikle elektrotlarda gerçekleşen kimyasal reaksiyonlar sonucu üretilen elektronlar dış bir devreden dolaşarak doğru akım (DC) üretilir. Kullanılan yakıt, elektrolit çeşidi (elektrolitten geçen iyon tipi) ve uygulama sıcaklığı gibi parametreler yakıt hücresi çeşitlerinde farklılıklar göstermektedir (Karanfil, 2020). Mikro kojenerasyon sistemlerinde uygulanan en popüler yakıt hücresi çeşitleri polimer elektrolit membran yakıt hücreleri (PEMYH) ve katı oksit yakıt hücreleridir (KOYH) (Ramadhani vd., 2019).

PEM yakıt hücresi teknolojisi, hızlı başlatma (düşük sıcaklıklarda çalışma nedeniyle), yüksek güç yoğunluğu ve düşük emisyonlar gibi bir dizi ek avantaj nedeniyle mikro-CHP sistemlerinde ana taşıyıcı olarak benimsenmesi için çok umut vericidir. PEM yakıt hücresi tabanlı mikro-CHP sistemine ait tipik konfügürasyon Şekil 8'de verilmiştir (Arsalis, 2019).

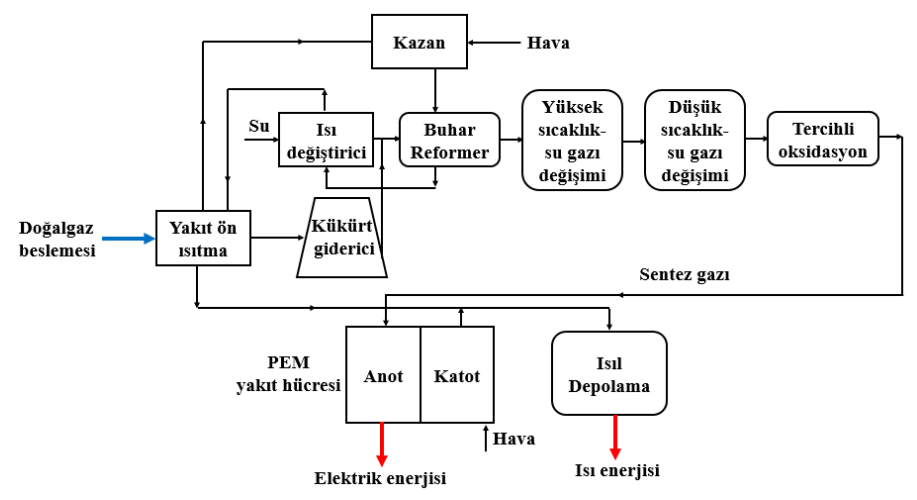

Şekil 8. PEM yakıt hücresi tabanlı mikro birleşik ısı ve güç sisteminin genel akış diyagramı

PEM yakıt hücrelerine kıyasla, katı oksit yakıt hücreleri (KOYH) çok daha yüksek sicaklıklarda $\left(1000{ }^{\circ} \mathrm{C}\right.$ 'ye kadar $)$ çalışmaktadırlar (Arsalis, 2019). KOYH'leri yüksek sıcaklıklarda çalışarak dâhili reformlama, daha fazla yakıt esnekliği, yakıt bileşimindeki ve kojenerasyon uygulamalarındaki değişikliklere daha az duyarlılık ve atık 1sıdan elektrik enerjisi üreten çevrimler (Organik Rankine döngüsü, buhar türbini vb.) ile kombinasyon oluşturma imkânı sağlamaktadır (Milcarek vd., 2017). KOYH tabakalı kojenerasyon sistemleri, verimlilik ve mesken yük profillerini karşılamaya uygunluk açısından farklı konfigürasyonlar için (Şeki19) değerlendirilebilir (Arsalis, 2019).

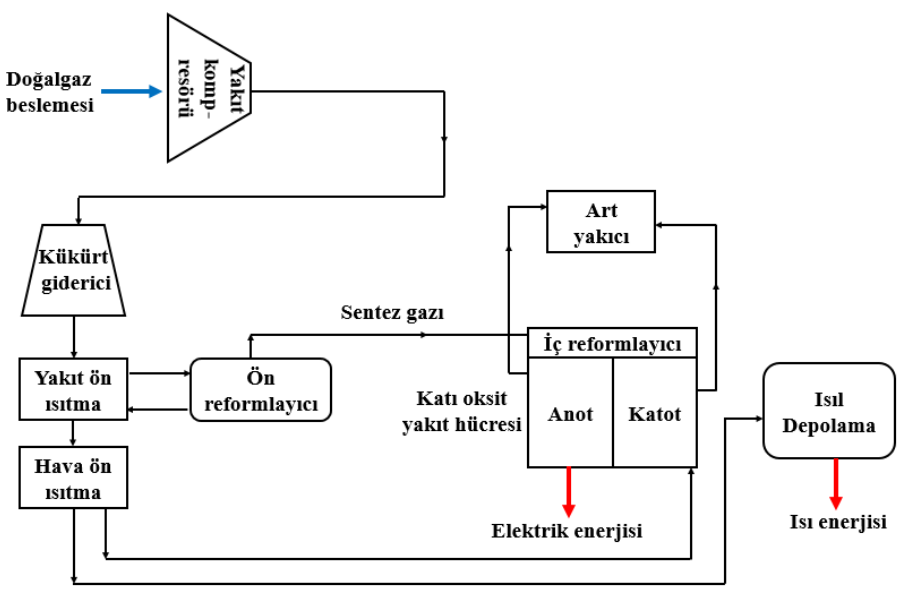

Şekil 9. Katı oksit yakıt hücresi tabanlı mikro birleşik ısı ve güç sisteminin genel akış diyagramı

Yakıt hücresi tabanlı kojenerasyon sistemlerinin yüksek yatırım maliyeti, geleneksel teknolojiler açısından hala en önemli dezavantajdır. Ticari yakıt hücresi tabanlı mikro-CHP sistemleri maliyetleri, Yakıt Hücreleri ve Hidrojen Ortak Girişimi (FCH-JU) hedeflerinden çok daha yüksektir. $\left[5 \mathrm{~kW}_{\mathrm{el}}\right.$ $\left.400 \mathrm{~kW}_{\mathrm{el}}\right]$ aralığında nominal güce sahip enerji sistemleri için FCH-JU, $3500 € / \mathrm{kW}_{\text {el }}$ ile $6500 € / \mathrm{kW}_{\text {el }}$ arasinda bir maliyet hedefi belirlemiştir (Loreti vd., 2019).

\subsection{Mikro Kojenerasyon Sistemlerinin Karşılaştırılması}

Hâlihazırda ticari olarak kullanılan mikro-CHP sistemleri incelendiğinde, yeni bir teknoloji olan yakıt hücreleri ve geleneksel teknoloji sahip sistemler olarak bir sinıflandırma 
yapılabilir. Yatırım maliyeti temelinde bir eşik belirleme yaklaşımı toplam sistem değerlendirmesi için yetersiz olduğu için, yakıt hücresi tabanlı mikro kojenerasyon sistemlerinin doğrudan geleneksel sistemlerle karşılaştırılması gerekmektedir. Gelecekteki fizibilite çalışmaları için tam ölçekli ve ticarileşmiş sistemleri değerlendirmek, zorunlu bir ihtiyaçtır. Yapılacak değerlendirmeler, sistemleri yaşam döngüsü maliyet düzeyinde inceleyebilmek için kullanım ömrü, yatırım maliyeti ve işletme maliyeti gibi birbiriyle ilişskili parametreleri de içermelidir. Yeni teknolojilerin, geleneksel ve/veya rakip teknolojilere göre nasıl performans gösterdiğini incelemek için elektriğin birim maliyeti gibi doğru tahminlere dayanan çalışmalarla değerlendirilmesi gerekmektedir. Karşılaştırılan teknolojilerin analizi, çeşitli yük profillerinin ve farklı koşulların da değerlendirmeye alınması ile konuma özgü hale getirilmelidir. Özellikle yük profili tüketimi (1s1-güç oranı dahil), hava koşulları, tüketici davranışı, ev tipi (kapasite ve enerji sınıfı dahil), kaynak kullanılabilirliği, yakıt maliyeti, altyapı, yenilenebilir kaynakların kullanılabilirliği gibi faktörler mutlaka dikkate alınmalıdır. Ayrıca, karbondan arındırma hususlarını da içerecek şekilde çevresel hedefler belirlenmelidir. Genel olarak, üzerinde en çok tartışılan teknoloji olan yakıt hücresi tabanlı mikro-CHP sistemlerinin ticarileştirilmesi büyük ölçüde teknik, ekonomik ve çevresel parametrelerin bir kombinasyonuna bağlı olacaktır (Arsalis, 2019).

Piyasada bulunan ve hâlihazırda konutlarda kullanılan farklı tipte mikro kojenerasyon sistemleri karşılaştırılması Tablo 1'de verilmiştir.

Tablo 1. Mikro Kojenerasyon Sistemlerinin Teknik ve Ekonomik Karşılaştırılması (Sungur vd., 2017)

\begin{tabular}{|l|c|c|c|}
\hline $\begin{array}{l}\text { Kojenerasyon } \\
\text { Sistem Tipi }\end{array}$ & $\begin{array}{c}\text { İçten Yanmalı } \\
\text { Motor }\end{array}$ & $\begin{array}{c}\text { Yakıt } \\
\text { Hücresi }\end{array}$ & $\begin{array}{c}\text { Mikro } \\
\text { Türbin }\end{array}$ \\
\hline $\begin{array}{l}\text { Sistem Kapasitesi } \\
\text { (kW) }\end{array}$ & 87,96 & 52,59 & 68,01 \\
\hline $\begin{array}{l}\text { Elektrik Üretim } \\
\text { Oranı }\end{array}$ & 0,568 & 0,475 & 0,441 \\
\hline $\begin{array}{l}\text { Termal Üretim } \\
\text { Oranı }\end{array}$ & 0,432 & 0,525 & 0,559 \\
\hline $\begin{array}{l}\text { Sistem Verimi } \\
\text { (\%) }\end{array}$ & 50,20 & 76,10 & 54,90 \\
\hline $\begin{array}{l}\text { Yatırım Maliyeti } \\
\text { (\$/kW) }\end{array}$ & 1256,25 & 4325,91 & 1310,10 \\
\hline $\begin{array}{l}\text { Y1llk Toplam } \\
\text { Gider (\$/kWYı1) }\end{array}$ & 525,94 & 415,28 & 493,88 \\
\hline $\begin{array}{l}\text { Y1llk Kar } \\
\text { (\$/kWY1) }\end{array}$ & 430,33 & 442,84 & 328,12 \\
\hline $\begin{array}{l}\text { Basit Amortisman } \\
\text { Süresi (Yı1) }\end{array}$ & 2,92 & 9,77 & 3,99 \\
\hline
\end{tabular}

Not: Tüm sistemlerin kapasite kullanım oranları 0,95 olarak, elektrik fiyatı 0,17\$/kWh, yakıt fiyatı da 0,043\$/kWh olarak kabul edilmiştir.

Tabloda sisteme giren toplam enerji, çıkan termal güç ve sistemin toplam verimleri ile ilgili bilgiler verilmiştir. Tabloda görüldüğü gibi birim güç başına en yüksek maliyet yakıt hücresi tabanlı sistemlerde, en düşük maliyet ise içten yanmalı motorlardadır. Ancak yıllık gider açısından durum tam ters olmaktadır. Birim güç başına en yüksek maliyet içten yanmalı motorda iken en düşük yıllık toplam gider yakıt hücresi tabanlı sistemlerde olmaktadır. Ancak en düşük amortisman süresi 2,9 yılla yine içten yanmalı motorlu sistemlerde olmaktadır. Yakıt hücresi tabanlı mikro kojenerasyon sistemleri diğer sistemlere e-ISSN: 2148-2683 göre daha yeni bir teknolojidir. Tablo 1'de görüldüğü üzere diğer mikro kojenerasyon sistemlerine göre yüksek verime sahip olmasına karşın ilk yatırım maliyeti yüksektir (Sungur vd., 2017). Yakıt hücresi sistemlerinde kimyasal enerji, geleneksel enerji dönüşüm sistemlerindeki birçok ara basamağın aksine doğrudan elektrik enerjisine çevrildiği için enerji dönüşüm verimi daha yüksek olmaktadır (Öztop ve Çıtlak, 2004; Akar vd., 2009).

Ticari mikro kojenerasyon sistemlerinin temel karakteristiklerinin karşılaştırılması Şekil 10'da verilmiştir. Karşılaştırma incelendiğinde, tüm sistemlerin kendi içlerinde değiştiği göze çarpmaktadır. Örneğin; Stirling motorlu mikro kojenerasyon sistemlerinin toplam verimi \%91-100 arasında değişiklik gösterirken, içten yanmalı motorlu mikro kojenerasyon sistemlerinin verimleri \%84-95,30 arasinda ve yakıt hücresi tabanlı sistemlerde ise toplam verim \%85-95 arasında değişiklik göstermektedir. Yakıt hücresi hariç diğer mikro kojenerasyon sistemlerinin elektriksel güç çıkışlarının termal güç çıkışlarından düşük olduğu şekilden açıkça görülmektedir. Ayrıca en yüksek verimin \%99.9 ile Cogen firmasına ait mikro Rankine kojenerasyon sistemlerine ait olduğu verilmiştir (Sungur vd., 2017).

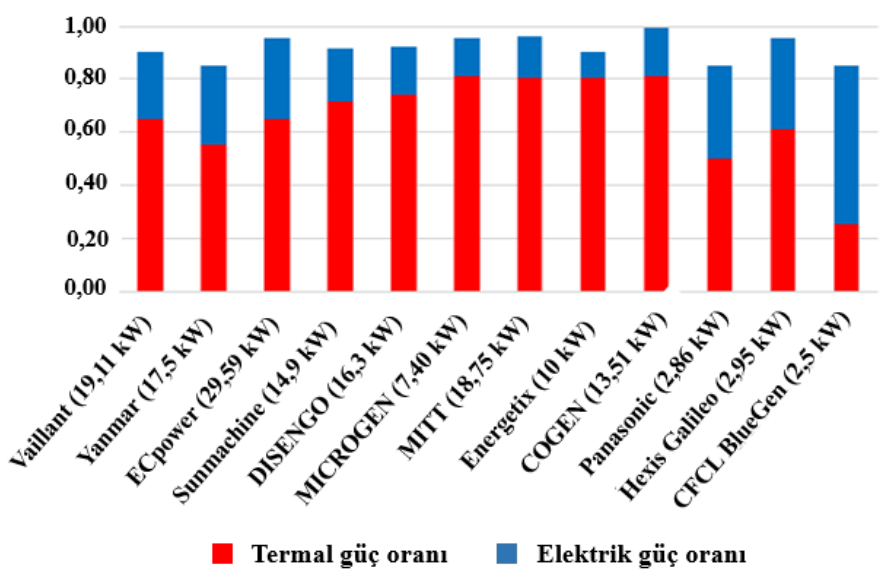

Şekil 10. Mikro kojenerasyon sistemlerinin temel karakteristiklerinin karşılaştırılması (Sungurvd., 2017).

\subsection{Mikro Kojenerasyon Sistemlerinin Dünyadaki Yeri}

Yap1 sektöründe enerji verimliliğini arttırmak son dönemlerde önemli bir hale gelmiştir (Ünver vd., 2020). Bunun sonucunda da, tek bir kaynaktan elektrik enerjisi üretmenin yanı sıra ortaya çıkan ısıl enerjiden yararlanılmasına olanak sağlayan mikro kojenerasyon sistemlerine duyulan ilgi artmış ve çalışmalar başlamıştır. $\mathrm{Bu}$ çalışmaların amaçları, kendi enerjilerini üreten ve mümkünse şebekeye bağımlılığı minimuma indiren sistemler tasarlamaktır. Evsel kojenerasyon sistemlerinde daha çok içten yanmalı motorlar ile birlikte yakıt olarak da benzin/doğalgaz tercih edilmektedir (Dorer vd., 2005).

İlk bölgesel 1sıtma sistemi 1877 yılında ABD'nin New York eyaletindeki Lockport' ta kurulmuştur İngiltere'de 1945 yılından itibaren gelişen bölge 1sıtması özellikle son 25 yıllık dönem içinde kojenerasyon sistemlerinin gelişmesi ile oldukça hızlı bir şekilde yaygınlaşmıştır (Çalapkulu, 2020). 2002 yılına gelindiğinde yaklaşık olarak 1000 adet mikro-CHP ünitesi evlerde faaliyete geçirilmiştir. İngiliz Hükümeti evsel 
kojenerasyon sistemi kullanımını hem enerji verimliliğinin yüksek olması hem de ekonomik getirisindeki avantajları nedeni ile desteklemiştir. "EnergySavingTrust" ve "CarbonTrust" enerji verimliliği politikalarını içeren teşvikler yayınlanmış, gerekli yasal ve teknik düzenlemeler ile yatırımcılar desteklenmiştir. Enerji üretimindeki \%17,5'lik vergi payı mikro-CHP sistemleri kullanıcıları için \%5'e düşürmüştür (Filoğlu, 2011).

Evsel kullanım için yakıt hücresi tabanlı mikro-CHP sistemlerinin ilk önemli lansmanı, Ene.Farm projesi ile Japonya'da gerçekleştirilmiştir. 31 Aralık 2018 itibarıyle Japonya'da toplam 292654 ticari Ene.Farm birimi konuşlandırılmıştır. Japon hükümeti, Ene.Farm programını uzun bir süre yüksek devlet yardımlarıyla desteklemiş, daha sonra endüstri olgunlaştıkça ve devlet yardımı gereksiz hale gelene kadar maliyetler düştükçe kademeli olarak azaltmıştır. Bir yakıt hücresi tabanlı mikro-CHP sistemi için yatırım maliyeti 24900 $€^{\prime}$ dan $9400 €^{\prime}$ ya düşürülmüştür (Gandiglio vd., 2020).

Ene.field projesi kapsamında (konut tipi yakıt hücresi mikro-CHP için Avrupa çapında saha denemeleri, 2011-2017), 10 ülkede konut ve ticari uygulamalar için, toplam kapasitesi yaklaşık $1155 \mathrm{~kW}$ olan 1000'den fazla küçük sabit yakıt hücresi sistemi tabanlı (1046 ünite: 603 KOYH ve 443 PEMYH) dağınık güç üretim sistemi kurulmuştur. Kurulu üniteler arasında, üretilen 4,5 milyon kWh'den fazla elektrik ile toplamda 5,5 milyon saatin üzerinde çalışma zamanına ulaşılmıştır. Şekil 11, Avrupa'daki Ene.field proje kurulumlarının bir haritasını göstermektedir (Gandiglio vd., 2020).

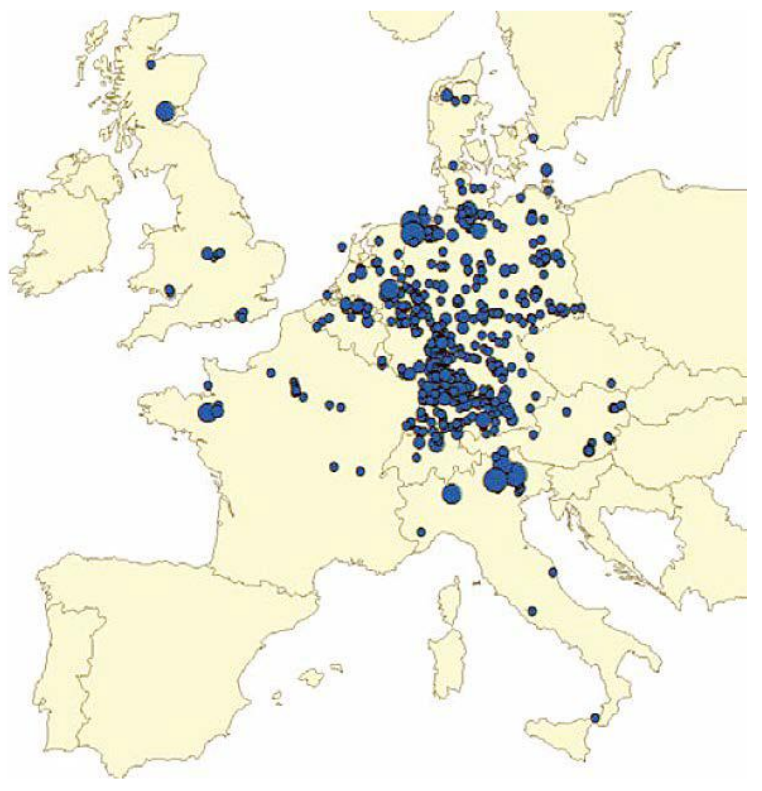

Şekil 11. Ene.Field projesinde gösterilen mikro-CHP birimlerinin yerleri (Gandiglio vd., 2020)

Türkiye'deki uygulamalar 2007'de çıkartılan 'Enerji Verimliliği' kanunu ile düzenlenmiş ve 2010 tarihinde yayınlanmış olan Elektrik Piyasasında Lisanssız Elektrik Üretim Yönetmeliği ile teşviklere başlanmıştır. $\mathrm{Bu}$ yönetmeliğe göre kullanıcılar çift yönlü sayaç ile ürettiğinden fazlasını şebekeye satabilecek ve $50 \mathrm{~kW}$ altı olan üretim sistemleri için lisans almak zorunda kalmayacaktır (Filoğlu, 2011).

Bazı Avrupa ülkelerindeki elektrik enerjisi üretiminde ve bölgesel 1sıtmada kullanılan kojenerasyon sistemleri için verilen destekler Tablo 2'de verilmiştir.
Tablo 2. Bazı Avrupa ülkelerindeki kojenerasyon sistemleri için verilen destekler (Çalapkulu, 2020).

\begin{tabular}{|l|l|}
\hline Ülkeler & Verilen Destekler \\
\hline Almanya & $\begin{array}{l}\text { Sabit prim, Vergi indirimi, Teşvikli piyasa } \\
\text { fiyatı, Yatırım tutarına bağlı \%30-40 hibe }\end{array}$ \\
\hline Avusturya & Yatırım harcama desteği \\
\hline Belçika & $\begin{array}{l}\text { Karbon emisyon kazanç sertifikası, Vergi } \\
\text { indirimi, Yatırım harcama desteği }\end{array}$ \\
\hline $\begin{array}{l}\text { Çek } \\
\text { Cumhuriyeti }\end{array}$ & $\begin{array}{l}\text { Sabit prim, Vergi indirimi, Satış garantili } \\
\text { projeler }\end{array}$ \\
\hline Finlandiya & $\begin{array}{l}\text { Sabit prim, Vergi indirimi, Yatırım harcama } \\
\text { desteği }\end{array}$ \\
\hline Fransa & $\begin{array}{l}\text { Sabit prim, Vergi indirimi, Teşvikli piyasa } \\
\text { fiyatı, Karbon emisyon kazanç sertifikası }\end{array}$ \\
\hline İtalya & $\begin{array}{l}\text { Vergi indirimi, Karbon emisyon kazanç } \\
\text { sertifikası }\end{array}$ \\
\hline Slovenya & 10 yıl garantili alım desteği \\
\hline Yunanistan & Teşvikli piyasa fiyatı \\
\hline
\end{tabular}

\section{Sonuç}

Nüfus artışının ve teknolojik gelişimin paralelinde artan enerji ihtiyacının karşılanmasında kojenerasyon sistemleri önemli bir rol oynamaktadır. Elektrik ve ısıl enerji ihtiyacının tek bir kaynaktan karşılanmasına yönelik evsel kojenerasyon sistemleri geliştirilmiştir. Yapılan çalışmada, evsel kojenerasyon sistemlerinin özellikleri, çeşitleri ve karşılaştırılmalarıyla birlikte Dünya'daki durumu incelenmiştir. Yapılan araştırmalar sonucunda evsel kojenerasyon sistemlerinin kurulumu ile ilgili tercih yapmadan önce ekonomik ve çevresel olarak dikkate alınması gereken bazı hususlar şu şekilde verilebilir:

- Ekonomik olarak bakıldığında, kurulum maliyeti, yıllık giderler ve geri ödeme süresinin, karşılaştırılabilir çevresel etmenlere bakıldığında ise, emisyon değerleri ve gürültü gibi göz ardı edilemeyecek etkenlerin birlikte incelenmesi gerekmektedir.

- İçten yanmalı motorlu sistemlerin avantajları; üretebileceği elektrik gücünün yüksek olması, yatırım maliyetinin ve geri ödeme süresinin az olması, dezavantajları ise gürültü ve yüksek emisyon değerleridir.

- Yakıt hücresi tabanlı sistemler ise emisyon değerlerinin ve yıllık bakım giderlerinin düşük olması ve çok sessiz bir çalışma sunması avantajlarına sahipken, ilk yatırım maliyetinin ve geri ödeme süresinin yüksek olması ticarileşmelerinin önündeki en büyük engeller olarak görülmektedir.

Sonuç olarak daha sessiz, çevreye duyarlı (düşük emisyon değerleri) bir sistem kurulması istendiğinde yakıt hücresi tabanlı kojenerasyon sistemleri tercih edilebilir. Ancak bu sistemler henüz çok yaygın üretime ve kullanıma geçmemiş olduğu için ekonomik değildir. Fakat evsel uygulamalardaki 1-50 kW'llk enerji ihtiyaçlarında; yüksek üretim gücü, daha ulaşılabilir ve kurulabilir bir teknolojiye sahip olması, kısa geri ödeme süresi gibi avantajlarından dolayı yaygın olarak içten yanmalı motorlu kojenerasyon sistemleri tercih edilmektedir. 


\section{Kaynakça}

Abuşoğlu, A., Demir, S., Kanoğlu, M. (2013) Biyogaz Beslemeli Gaz Motorlu Bir Kojenerasyon Sisteminin Termoekonomik Analizi, Isı Bilimi ve Tekniği Dergisi, 33, 09-21.

Akar, E., Genç, F., Sağlam, G., Baranak, M., Korkmaz, Ö.C., Obut, S., Akgün, F. (2009) Evsel Mikro Kojenerasyon Uygulamaları ile Enerji Verimliliğinin Arttırılması, Tesisat Mühendisliği Dergisi, 112, 62.

Arsalis, A. (2019) A comprehensive review of fuel cell-based micro-combined-heat-and-power systems, Renewable and Sustainable Energy Reviews 105, 391-414.

Belth, R. (2011) Small and micro combined heat and power (CHP) systems: Advanced design, performance, materials and applications, Woodhead Publishing, 3.

Boyce, M.P. (2010) Handbook For Cogeneration and Combined Cycle Power Plants Second Edition, ASME Press, 31.

Ciampi, G., Rosato, A., Scorpio, M., Sibilio, S. (2016) Energy Performance of A Residential Building-Integrated MicroCojeneration System Upon Varying Thermal Load And Control Logic, International Journal of Low-Carbon Technologies, 11, 75-88.

Çalapkulu, S.R. (2020) Kojenerasyon Sistemleri ve Trijenerasyon Sistemleri, Mühendis ve Makine, 53-62.

Çengel, Y.A. ve Boles, M.A. (2013) Mühendislik Yaklaşımıyla Termodinamik, McGraw-Hill, 551-587.

Demir, H, Çıracı, G, Kaya, R, Ünver, Ü. (2020) Aydınlatmada Enerji Verimliliği: Yalova Üniversitesi Mühendislik Fakültesi Durum Değerlendirmesi. Uludağ University Journal of The Faculty of Engineering, 25 (3), 1637-1652.

Dorer, V., Weber, R., Weber, A. (2005) Performance assessment of fuel cell micro-cojeneration systems for residential buildings, Elsevier, 1133-1135.

Ener Ruşen, S., Topçu, M.A., Karanfil Celep, G., Çeltek, S.A., Ruşen, A. (2018) Üniversite Kampüs Binaları için Enerji Etüdü: Örnek Çalışma, Çukurova Üniversitesi Mühendislik Mimarlık Fakültesi Dergisi, 33, 83-92.

Erbıyık, H., Çatal, T., Durukan, S., Topaloğlu, D.G., Ünver, Ü. (2021) Assessment of Yalova University Campus According to LEED V.4 Certification System. Environmental Research and Technology, 1, 1-17.

Ferguson, A., Kelly, N., Weber, A., Griffith, B. (2009) Modelling residential-scale combustion-based cojeneration in building simulation, Journal of Building Performance Simulation, 2, 1-14.

Filoğlu, E. (2011) Türkiye'de Mikro Kojenerasyon, Türkiye Kojenerasyon ve Temiz Enerji Teknolojileri Derneği, 88, 16.

Flin, D. (2009) Cogeneration: A user's guide, The Institution of Engineering and Technology.

Forsthoffer, W.E. (2011) Forsthoffer's Best Practice Handbook for Rotating Machinery, Butterworth-Heinemann, Elsevier.

Frangopoulos, C.A. (2017) Cogeneration: Technologies, optimization and implementation, The Institution of Engineering and Technology, 1.

Fuchs, E.F. ve Masoum, M.A.S. (2011) Power Conversion of Renewable Energy Systems, Springer.

Gandiglio, M., Ferrero, D., Lanzini, A., Santarelli, M. (2020) Fuel cell cogeneration for building sector: European status, REHVA Journal, 21-25.

Goswami, D.Y. ve Kreith, F. (2016) Energy Efficiency and Renewable Energy Handbook, Second Edition, CRC Press, 892-893.
Horlock, J.H. (2003) Advanced Gas Turbine Cycles, Elsevier Pergamon.

International Energy Agency (IEA), (April 2009) Co-Generation and District Energy.

Karanfil, G. (2020) Proton Değişim Membran Yakıt Hücreleri: Termodinamiği, Bileşenleri ve Uygulama Alanları, Mühendis ve Makine, 61, 57-76.

Karanfil, G., Ener Ruşen, S., Poyraz, Ş.N., Can, M. (2020) Atık Isı Geri Kazanım Sistemleri ve Isıl Verim Parametrelerinin Deneysel İncelenmesi, Avrupa Bilim ve Teknoloji Dergisi, 19, 127-137.

Kaya, D., Öztürk, H.H., Kayfeci, M. (2017) Hidrojen ve Yakıt Pili Teknolojisi, Umuttepe Yayınları.

Khartchenko, N.V. ve Khartchenko, V.M. (2014) Advanced Energy Systems, CRC Press, 206-231.

Kolanowski, B.F. (2011) Small-scale Cojeneration Handbook Fourth Edition, The Fairmont Press, 11-44.

Loreti, G., Facci, A.L., Peters, T., Ubertini, S. (2019) Numerical modeling of an automotive derivative polymer electrolyte membrane fuel cell cogeneration system with selective membranes, International Journal of Hydrogen Energy, 44, 4508-4523.

McLean-Conner, P. (2009) Energy Efficiency: Principles and Practices, PennWell Corporation.

Milcarek, R.J., Ahn, J., Zhang, J. (2017) Review and analysis of fuel cell-based, microcogeneration for residential applications: Current state and future opportunities, Science and Technology for the Built Environment, 23, 1224-1243.

Moran, M.J., Shapiro, H.N., Boettner, D.D., Bailey, M.B. (2014) Fundamentals of Engineering Thermodynamics, John WILEY and Sons, 442-480.

Onovwiona, H.I ve Ugursal, V.I. (2006) Residential cogeneration systems: Review of the current technology, Renewable and Sustainable Energy Reviews 10, 389-431.

Öztop, H.F. ve Çıtlak, A. (2004) Yakıt Pilli Kojenerasyon Sistemlerinin Evsel ve Ticari Binalarda Uygulamalar1, Tesisat Mühendisliği Dergisi, 82, 42-44.

Pravadalıoğlu, S., Yerinde Enerji Üretimi- Kojenerasyon Sistemleri, II. Elektrik Tesisat Ulusal Kongresi, 24-27 Kasım 2011, İzmir.

Pulkrabek, W.W. (1997) Engineering Fundamentals of the Internal Combustion Engine, Pearson Education, Prentice Hall.

Ramadhani, F., Hussain, M.A., Mokhlis, H. (2019) A Comprehensive Review and Technical Guideline for Optimal Design and Operations of Fuel Cell-Based Cogeneration Systems, Processes, 7, 950.

Sun, L., Jin, Y., Shen, J., You, F. (2021) Sustainable Residential Micro-Cogeneration System Based on a Fuel Cell Using Dynamic Programming-Based Economic Day-Ahead Scheduling, ACS Sustainable Chemical Engineering, Doi:10.1021/acssuschemeng.0c08725

Sungur, B., Özdoğan, M., Topaloğlu, B., Namlı, L. (2017) Küresel Enerji Tüketimi Bağlamında Mikro Kojenerasyon Sistemlerinin Teknik ve Ekonomik Değerlendirilmesi' Mühendis ve Makine, 58, 14-15.

Tanaka, N. (2009) Cogeneration and District Energy: Sustainable Energy Technologies for Today and Tomorrow, International Energy Agency (IEA), 15.

Thulukkanam, K. (2013) Heat Exchanger Design Handbook Second Edition, CRC Press.

United States Environmental Protection Agency (US EPA), (2008) EPA's Report on Environment. 
Ünver, Ü. ve Kılıç, M. (2005) Bir Kombine Çevrim Güç Santralinin Termodinamik Analizi, Mühendis ve Makine, 46, 47-56.

Ünver, Ü., Kılıç, M. (2007) Second Law Based Thermoeconomic Analysis of Combined Cycle Power Plants Considering The Effects of Environmental Temperature and Load Variations, International Journal of Energy Research, 31, 148-157.

Ünver, Ü., Kılıç, M. (2017) Influence of Environmental Temperature on Exergetic Parameters of A Combined Cycle Power Plant. International Journal of Exergy, 22, 73-88.

Ünver Ü., Kelesoglu, A., Kilic, M. (2018) A Novel Method for Prediction of Gas Turbine Power Production: Degree-Day Method, Thermal Science, 22, 809-817.
Ünver, Ü., Adıgüzel, E., Adıgüzel, E., Çivi, S., Roshanaei, K. (2020) Türkiye'deki İklim Bölgelerine Göre Binalarda Isı Yalıtım Uygulamaları, İleri Mühendislik Çalışmaları ve Teknolojileri Dergisi, 1, 171-187.

Wang, S.K. (2001) Handbook of Air Conditioning and Refrigeration, McGraw-Hill.

Whitman, W.C., Johnson, W.M., Tomczyk, J.A., Silberstein, E. (2013) Refrigeration \& Air Conditioning Technology: 25th Anniversary, Delmar, Cengage Learning.

Yavuzdeğer, A. ve Ekinci, F. (2019) Performance Analysis of Grid-Connected Micro-Cojeneration System Based on The Internal Combustion Engine, European Mechanical Science, 3, 164-169. 